УДК 656.34:338.47

\title{
МЕТОДИЧНИЙ ПІДХІД ЩОДО ВИБОРУ РАЩІОНАЛЬНОГО ВАРІАНТУ РОЗВИТКУ МІСЬКИХ ПАСАЖИРСЬКИХ ПЕРЕВЕЗЕНЬ
}

\author{
Бараш Ю. С., д.е.н., професор, \\ Адамян Ю. П., асистент (ДНУЗТ)
}

\begin{abstract}
Анотація. Мета. Розробка методичного підходу щуодо вибору раџіонального варіанту розвитку міських пасажирських перевезень в умовах сталого розвитку з урахуванням переваг $і$ недоліків кожного виду міського пасажирського транспорту. Методика. Для вирішення завдань такого класу в роботі запропоновано застосувати системний підхід, методи раціонального вирішення проблем $і$ стратегічне планування за певним сиенарісм. Результати. Для вирішення завдання оптимального розвитку транспорту у великих містах слід застосувати такий економічний критерій, який міг би врахувати найбільшу кількість факторів, які адекватно описують поведінку моделі реформування. Оиінити всі вищевказані фактори в одній роботі дуже складно, тому автори зробили спробу розробити спільний науковий підхід до вирішення цієї проблеми і одночасно розробити методи оцінки витрат на боротьбу зі збитком навколишньому середовищу, здоров'ю жителів міста $і$ на компенсацію збитків від технологічних пробок. Наукова новизна. У роботі розроблений узагальнюючий показник оцінки ефективності міських пасажирських перевезень, заснований на поєднанні коефіцієнтів, щзо характеризують: економічну ефективність міського пасажсирького транспорту з урахуванням обсягів інвестицій на утримання i розвиток транспортної інфраструктури; техногенну обстановку, яку створює транспорт в місті; збиток, який кожен вид транспорту завдає довкіллю $i$ суспільству. Запропонований показник дозволяє об'єктивно порівняти ефективність пасажирських перевезень по кожному виду транспорту окремо. Практична значимість. Врахування зазначеного узагальнюючого показника оцінки ефективності міських пасажирських перевезень дозволить міським органам виконавчої влади приймати науково обгрунтовані рішення щэодо розвитку пасажирського транспорту великих міст на перспективу.
\end{abstract}

Ключові слова: міський транспорт, збиток суспільству та навколищньому середовищу, впливові фактори, моделі реформування, критерій оптимальності, узагальнюючий показник ефективності.

\section{МЕТОДИЧЕСКИЙ ПОДХОД К ВЫБОРУ РАЦИОНАЛЬНОГО ВАРИАНТА РАЗВИТИЯ ГОРОДСКИХ ПАССАЖИРСКИХ ПЕРЕВОЗОК}

\author{
Бараш Ю. С., д.э.н., профессор, \\ Адамян Ю. П., ассистент (ДНУЖТ)
}

\begin{abstract}
Аннотация. Цель. Разработка методического подхода к выбору рационального варианта развития городских пассажирских перевозок в условиях устойчивого развития с учетом преимуществ и недостатков каждого вида городского пассажирского транспорта. Методика. Для решения задач такого класса в работе предложено применить системный подход, методы рационального решения проблем и стратегическое планирование по определенному сценарию. Результаты. Для решения задачи оптимального развития транспорта в крупных городах следует применить такой экономический критерий, который мог бы учесть наибольшее количество факторов, которые адекватно описывают поведение модели реформирования. Оченить все вымеуказанные факторы в одной работе очень сложно, поэтому авторы сделали попьтку разработать общий научный подход к решению этой проблемь и одновременно разработать методы оченки затрат на борьбу с ущербом окружающей среде, здоровью жителей города и на компенсаџии ущерба от технологических пробок. Научная новизна. В работе разработан обобщающий показатель оценки эффективности городских пассажирских перевозок, основанный на сочетании коэффиџиентов, характеризующих: экономическую эффективность городского пассажирского транспорта с учетом объемов инвестиций на содержание и развитие транспортной инфраструктуры; техногенную обстановку, которую создает транспорт $в$ городе; ущерб, который каждый вид транспорта наносит окружающей среде и обществу. Предложенный показатель позволяет объективно сравнить эффективность пассажирских перевозок по каждому виду транспорта отдельно. Практическая значимость. Учет указанного обобщающего показателя оченки эффективности городских пассажирских перевозок позволит городским органам
\end{abstract}

(C) Бараш Ю.С.,

Адамян Ю.П.
Вісник економіки транспорту і промисловості № 49, 2015 
исполнительной власти принимать научно обоснованные решения по развитию пассажирского транспорта крупных городов на перспективу.

Ключевые слова: городской транспорт, ущерб обществу и окружающей среде, влиятельные факторы, модели реформирования, критерий оптимальности, обобщцающий показатель эфрективности.

\title{
SYSTEMATIC APPROACH TO THE CHOICE OF RATIONAL VARIANT OF DEVELOPMENT OF URBAN PASSENGER TRANSPORTATIONS
}

\author{
Barash Yu. S., Doctor of Economics, Professor, \\ Adamyan Yu., Assistant \\ (Dnipropetrovsk National University of Railway Transport named)
}

\begin{abstract}
Summary. The purpose. Development of a methodological approach to the choice of a rational variant of urban passenger transport in the context of sustainable development, taking into account the advantages and disadvantages of each type of urban passenger transport. Methods. To solve the problems of this class in the work proposed to apply a systematic approach, methods of rational problem solving and strategic planning for a particular scenario. Results. To solve the problem of optimal development of transport in large cities to apply an economic criterion that would take into account the largest number of factors which adequately describe the behavior of the model of reform. Evaluate all the above factors in the same work is very difficult, so the authors have made an attempt to develop a common scientific approach to solving this problem and at the same time to develop methods for evaluating the costs of combating damage to the environment, the health of residents of the city and on the Compensation technology plugs. Scientific novelty. In this paper we developed a general indicator of evaluating the effectiveness of urban passenger transport, based on a combination of factors that characterize: the cost-effectiveness of urban transport, considering the amount of investment for the maintenance and development of transport infrastructure; man-made environment posed by transport in the city; damage each type of sediment transport environment and society. The proposed indicator provides objectively compare the effectiveness of passenger traffic for each mode separately. The practical significance. Allowance for this summary measure evaluating the effectiveness of urban passenger transport will allow the city executive authorities to take evidence-based decisions on the development of passenger transport of large cities in the future.
\end{abstract}

Keywords: urban transport, damage to society and the environment, influential factors, restructuring, optimality criterion, a general indicator of efficiency.

Постановка проблеми. Для вибору раціонального варіанту розвитку міських пасажирських перевезень та удосконалення в цілому функціонування системи міського пасажирського транспорту потрібно розглядати сукупний вплив факторів різного характеру (технічних, економічних, соціальних, природних), оцінюючи їх роль та значущість за допомогою відповідного кількісного критерію. Задача вибору критерію оптимальності вимагає застосувати такий критерій, який би міг врахувати найбільшу кількість чинників, що адекватно описують поведінку моделі реформування транспортної компанії будь-якого типу, порівняти між собою кілька варіантів транспортних перевезень пасажирів та вибрати 3 них найкращий за узагальнюючим показником оцінки ефективності міських пасажирських перевезень, який грунтується на поєднанні коефіцієнтів, що характеризують: економічну ефективність міського пасажирського транспорту з урахуванням обсягів інвестицій на утримання та розвиток транспортної інфраструктури; техногенну обстановку, яку створює транспорт у місті; шкоду, яку кожний вид транспорту завдає довкіллю та суспільству.

Формування цілей статті (постановка завдання). Розробка методичного підходу щодо вибору раціонального варіанту розвитку міських пасажирських перевезень в умовах сталого розвитку 3 урахуванням переваг та недоліків кожного виду міського пасажирського транспорту.

Аналіз останніх досліджень і публікацій. Останні наукові публікації досить часто висвітлюють питання розвитку пасажирських транспортних перевезень у великих містах. Особливо слід відмітити праці Гаєвської Л. Н., Зеркалова Д. В., Качан Є. П., Кудрицької Н. В., Сидоренко І. В. та ін. Водночас, розвиток міських транспортних перевезень пасажирів відбувається під впливом факторів, які впливають на їх розмішення та функціонування, що вимагає постійного моніторингу іх впливу на тенденції розвитку міського пасажирського транспорту.

Недостатня розробленість теоретикометодичних засад реформування міського транспорту зумовлюе необхідність розробки 
наукових принципів, які б враховували усі перелічені вище фактори за умови сталого розвитку суспільства, що визначає актуальність теми дослідження, iii теоретичну та прикладну значущість.

\section{Виклад основного матеріалу}

дослідження. В останні роки розвиток міського транспорту в Україні вирішується без урахування шкоди, яку він завдає населенню та навколишньому середовищу. Але в той же час $\epsilon$ багато наукових праць вітчизняних та закордонних вчених, які пропонують вирішувати цю проблему 3 урахуванням загальних зовнішніх витрат на боротьбу з негативними наслідками від діяльності міського транспорту на довкілля. Наприклад, в країнах Євросоюзу ведеться моніторинг оцінки шкоди, яку завдають суспільству різні види транспорту (табл. 1).

Таблиияя 1

Загальні зовнішні витрати для країн Євросоюзу, млрд євро. Джерело: [11]

\begin{tabular}{|c|c|c|c|c|c|c|c|c|c|c|c|}
\hline \multirow[t]{3}{*}{ Країна } & \multirow{3}{*}{ 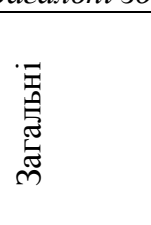 } & \multicolumn{5}{|c|}{ Автомобільний транспорт } & \multicolumn{2}{|c|}{ Поїзди } & \multicolumn{2}{|c|}{ Авіація } & \multirow{3}{*}{ 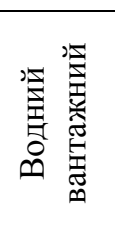 } \\
\hline & & \multirow{2}{*}{ 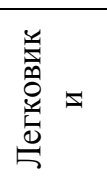 } & \multirow{2}{*}{ 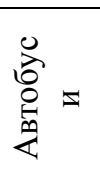 } & \multirow{2}{*}{$\begin{array}{l}\text { 弟 } \\
\text { 总 } \\
\stackrel{0}{0}\end{array}$} & \multicolumn{2}{|c|}{ Вантажівки } & \multirow{2}{*}{ 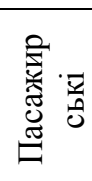 } & \multirow{2}{*}{ 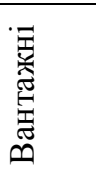 } & \multirow{2}{*}{ 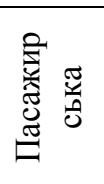 } & \multirow{2}{*}{ 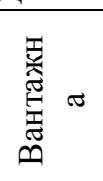 } & \\
\hline & & & & & 离 & ... & & & & & \\
\hline Австрія & 16,6 & 7,4 & 0,2 & 0,8 & 0,4 & 6,3 & 0,1 & 0,15 & 1,2 & 0,05 & 0,03 \\
\hline Бельгія & 22,3 & 10,9 & 0,3 & 0,3 & 1,5 & 5,8 & 0,2 & 0,1 & 2,5 & 0,45 & 0,15 \\
\hline Данія & 11,1 & 4,1 & 0,6 & 0,2 & 0,6 & 3,6 & 0,2 & 0,06 & 1,6 & 0,17 & 0 \\
\hline Фінляндія & 7,3 & 3,6 & 0,4 & 0,05 & 0,5 & 1,5 & 0,1 & 0,10 & 0,9 & 0,04 & 0,01 \\
\hline Франція & 87,5 & 35,4 & 2,1 & 2,6 & 15,1 & 18,9 & 0,7 & 0,55 & 11,1 & 0,82 & 0,17 \\
\hline Германія & 149,1 & 70,8 & 2,9 & 4,6 & 7,1 & 43,7 & 2,4 & 1,50 & 13,7 & 1,26 & 1,17 \\
\hline Греція & 13,5 & 4,4 & 0,2 & 1,6 & 1,8 & 3,1 & 0,05 & 0,01 & 2,2 & 0,10 & 0 \\
\hline Ірландія & 6,8 & 2,6 & 0,2 & 0,1 & 0,4 & 2,1 & 0,04 & 0,02 & 1,2 & 0,07 & 0 \\
\hline Італія & 95,2 & 42,1 & 2,5 & 9,9 & 7,2 & 24,9 & 1,1 & 0,5 & 6,7 & 0,36 & 0 \\
\hline Люксембург & 1,6 & 0,7 & 0,1 & 0,03 & 0,03 & 0,4 & 0,02 & 0,02 & 0,1 & 0,16 & 0,01 \\
\hline Нідерланди & 30,5 & 9,7 & 0,4 & 0,7 & 0,03 & 10,9 & 0,4 & 0,05 & 6,4 & 0,84 & 1,08 \\
\hline Норвегія & 7,9 & 3,8 & 0,4 & 0,2 & 0,5 & 1,5 & 0,1 & 0,06 & 1,4 & 0,05 & 0 \\
\hline Португалія & 12,7 & 3,8 & 0,2 & 1,2 & 1,4 & 4,2 & 0,1 & 0,06 & 1,6 & 0,07 & 0 \\
\hline Іспанія & 58,2 & 21,0 & 0,6 & 1,5 & 13,2 & 12,0 & 0,4 & 0,18 & 9,1 & 0,18 & 0 \\
\hline Швеція & 13,7 & 6,4 & 0, & 0,2 & 0,9 & 3,3 & 0,1 & 0,18 & 1,8 & 0,12 & 0 \\
\hline Швейцарія & 13,8 & 6,6 & 0,3 & 0,5 & 0,6 & 2,1 & 0,2 & 0,2 & 3,3 & 0,18 & 0 \\
\hline Великобританія & 102,6 & 47,6 & 3,2 & 1,0 & 7,6 & 19,8 & 1,6 & 0,7 & 19,8 & 1,36 & 0,01 \\
\hline Всього ЄС & 650,3 & 281 & 15,1 & 25,5 & 58,8 & 164 & 7,8 & 4,5 & 84,7 & 6,3 & 2,6 \\
\hline
\end{tabular}

Крім того, для країн Євросоюзу факторами (аварії, шум, забруднення повітря, періодично розраховуються середньорічні загальні зміна клімату, вплив на природу, міські та та питомі витрати на боротьбу зі шкідливими індустріальні ефекти). наслідками від транспорту окремо за різними

Таблиия 2

Розподіл витрат на боротьбу зі шкідливии наслідками. Джерело: [11]

\begin{tabular}{|l|c|c|}
\hline \multirow{2}{*}{ Фактор } & Вартість витрат на боротьбу зі шкідливими наслідками \\
\cline { 2 - 3 } & 156 & відсотки \\
\hline Аварії & 46 & 24 \\
\hline Шум & 175 & 7,1 \\
\hline Забруднення повітря & 196 & 27 \\
\hline Зміна клімату & 20 & 30,1 \\
\hline Вплив на природу & 10 & 3,1 \\
\hline Міські ефекти & 47 & 1,5 \\
\hline Індустріальні ефекти & 650 & 7,2 \\
\hline Всього & & 100 \\
\hline
\end{tabular}


Перша спроба розрахувати вказані витрати від перевезень різними видами транспорту між містами України була зроблена в дисертаційній роботі Чаркіної Т. Ю., результати якої представлені у табл. 3 .

Табличя 3

Загальні очікувані зовнішні витрати транспорту Украӥни на боротьбу зі шкідливим впливом на суспільство та довкілля, млрд грн. Джерело: [11]

\begin{tabular}{|c|c|c|c|c|}
\hline \multirow{2}{*}{$\begin{array}{c}\text { Причини шкідливого } \\
\text { впливу }\end{array}$} & \multicolumn{4}{|c|}{ Витрати для конкуруючих видів транспорту } \\
\hline & $\begin{array}{c}\text { Легкові } \\
\text { автомобілі з } \\
\text { урахуванням } \\
\text { власних } \\
\text { автомобілів }\end{array}$ & Автобуси & $\begin{array}{c}\text { Пасажирські } \\
\text { поїзди }\end{array}$ & Всього витрат \\
\hline Аварії & 20,06 & 1,05 & 0,04 & 21,15 \\
\hline Шум & 0,96 & 0,16 & 0,47 & 1,59 \\
\hline $\begin{array}{l}\text { Забруднення } \\
\text { повітря }\end{array}$ & 1,87 & 2,11 & 0,62 & 4,60 \\
\hline Зміна клімату & 1,58 & 0,44 & 0,09 & 2,11 \\
\hline Індустріальний ефект & 0,96 & 0,50 & 0,39 & 1,85 \\
\hline Всього, млрд грн & 25,43 & 4,26 & 1,61 & 31,30 \\
\hline
\end{tabular}

Якщо проаналізувати статистичні данні обласних місцевих адміністрацій України стосовно забруднення міст від роботи міських видів пасажирського транспорту, то вони наводять лише загальну інформацію забруднення довкілля від різних факторів, за якою не можна зробити висновки щодо раціонального розвитку системи транспорту великого міста 3 урахуванням переваг та недоліків кожного 3 них, а також не можливо визначити такі питання, як:

- очікувані зовнішні витрати міського транспорту на боротьбу зі шкідливим впливом на суспільство та довкілля;

- вплив міського транспорту на здоров'я мешканців міста; заторів;

- втрату часу пасажирів від технологічних

- втрати доходів підприємств від затримки вантажів у технологічних заторах;

- витрати, які несуть громадяни міста учасники дорожньо-транспортних подій (ДТП) i страхові компанії на оплату медичних послуг у зв'язку 3 втратою годувальника, або членів їх родин.

До проблеми перевезення пасажирів міським транспортом великого міста слід підходити з різних поглядів: місцевих органів влади, мешканців міста та перевізників в особі транспортних компаній будь-якої власності (рис. 1).

Місцеві органи влади турбують питання:
- зменшення шкоди довкіллю, здоров’ю громадян і потребують менше коштів на боротьбу з їх усунення та на розвиток міського транспорту;

- зменшення впливу на техногенну обстановку міста (технологічні пробки, аварії, швидкість поїздки всіх видів транспорту);

- соціальна спрямованість міського транспорту.

Пасажирів турбують такі фактори:

- ціна послуги;

- ритмічність перевезень;

- якість перевезень;

- швидкість поїздки та кількість пересадок;

- зручність та термін очікування поїздки;

- безпечність поїздки для життя пасажира. Потреби перевізників зовсім інші. Їх, насамперед, турбують економічні питання: рентабельність перевезень; зростання обсягів перевезень 3 мінімальними витратами; отримання дотацій від місцевих органів влади або Уряду.

Аналізуючи сказане вище, можна заключити, що для вибору найкращого варіанту розвитку пасажирського транспорту великого міста необхідно розробити критерій оптимальності, який би враховував максимальну кількість впливових факторів та одночасно задовольняв би погляди місцевих органів влади, перевізників та мешканців міста.

Зараз існує кілька підходів до проблеми реформування міського транспорту у великих містах України (рис. 2). 


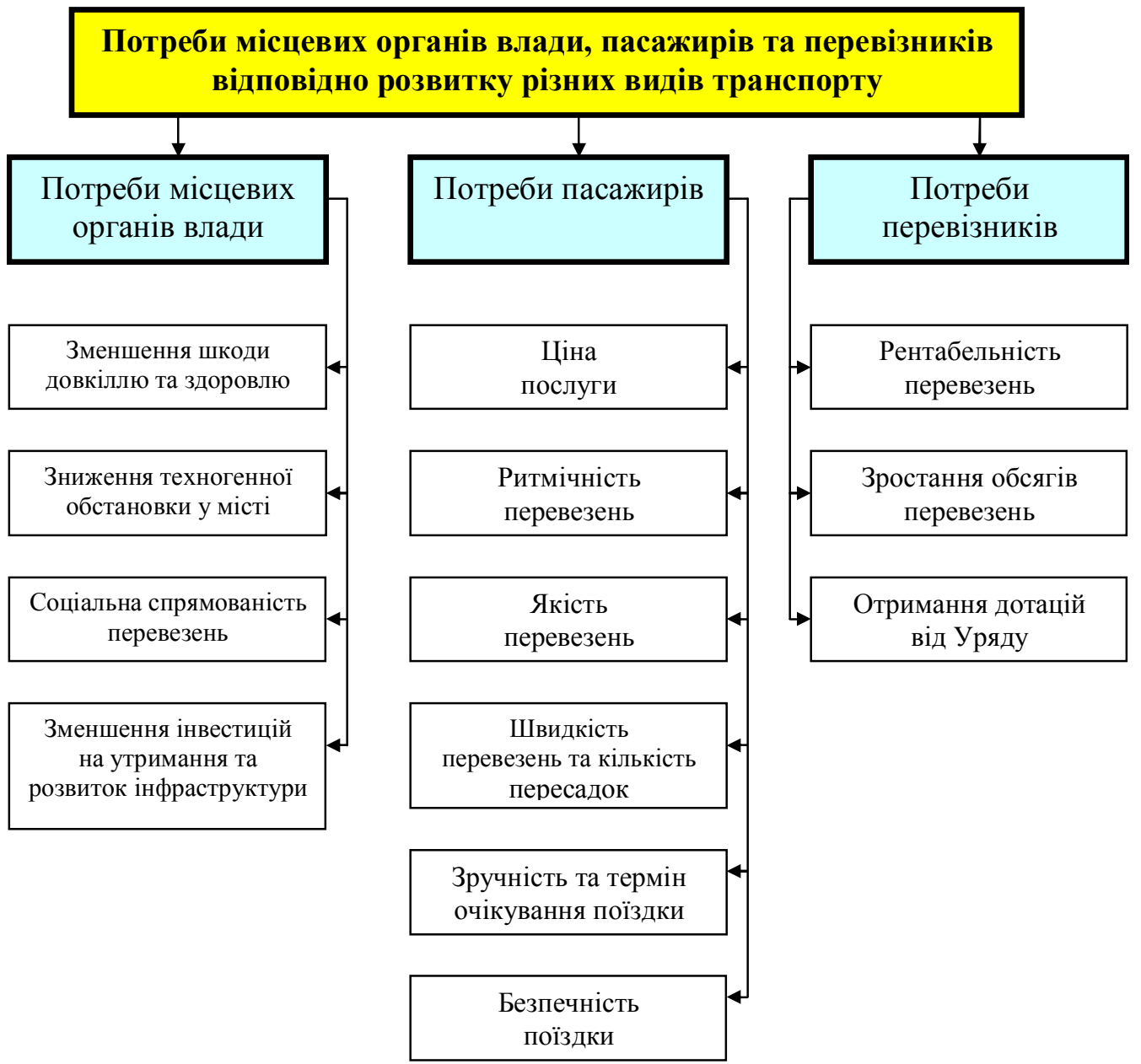

Рис. 1 - Потреби місиевих органів влади, пасажирів та перевізників на розвиток міського транспорту. Джерело: [11] з доробкою автора

Периий підхід пов'язаний з реанімацією монополії держави на пасажирські перевезення на ринку міських транспортних послуг, збереженням структури управління міським транспортом та власності на його майно за комунальними підприємствами.

Другий nidxid полягає в необхідності зміни структури ринку міських послуг з монопольної на олігополію, організації монопольного середовища на володіння транспортною інфраструктурою та конкурентного середовища на перевезення пасажирів.

Tpemiü nidxid являє собою поєднання першого та другого підходів, яке дозволяе передачу у конкурентне середовище частину автомобільних, річкових, морських та приміських пасажирських перевезень, оскільки інші види міського транспорту є соціально спрямованими та збитковими i потребують централізованого управління з боку місцевих органів влади.
Кожний $з$ цих підходів має свої переваги та недоліки. Ефективна робота міського транспорту в стані природної монополії можлива тільки за умови стабільного державного фінансування та адаптування структури управління до сучасних ринкових умов. До його переваг слід віднести соціальну захищеність працівників, налагоджені стабільні пасажирські перевезення, отримання дотацій місцевих бюджетів та Уряду на розвиток інфраструктури міського транспорту та придбання рухомого складу. До недоліків слід віднести збитковість пасажирських перевезень, дуже велику зношеність рухомого складу, відсутність необхідної кількості трамваїв, тролейбусів, автомобілів, автобусів, вагонів метро, річкового та морського транспорту, відсутність державних інвестицій, обмежене впровадження новітніх технологій, нових видів перевезень, рухомого складу нового покоління та інше. 


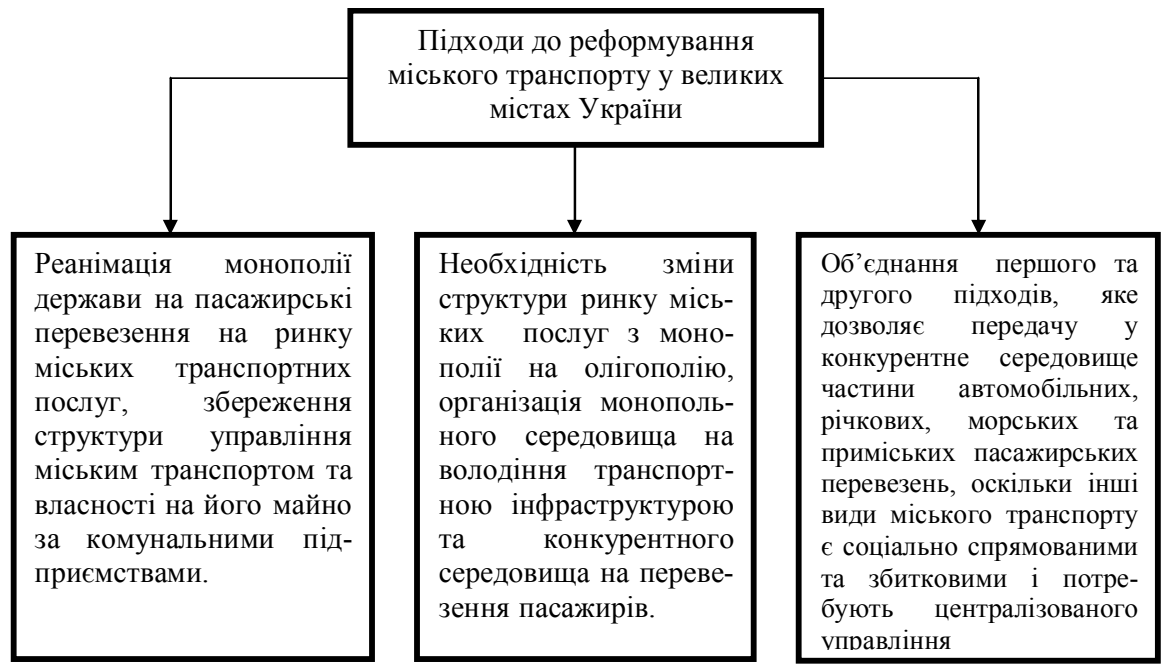

Рис. 2 - Три підходи до реформування міського транспорту у великих містах. Джерело: Розробка автора

Реалізація другого підходу дозволяє уникнути деяких недоліків, що властиві першому підходу: частково вирішити проблему розвитку міського транспорту, оновлення парків рухомого складу за приватні кошти, приватизації окремих ремонтних підрозділів та ін. До недоліків другого підходу слід віднести відсутність стабільності в роботі операторів, зменшення обсягів соціальної захищеності їх робітників, децентралізацію єдиного механізму управління міським транспортом та інше.
Третій підхід до проблеми реформування міського транспорту має ті ж переваги та недоліки, що і другий підхід, тільки відрізняється від нього зменшенням кількості коштів на придбання рухомого складу.

Вибір найкращого варіанта експлуатації та розвитку транспортного ринку міських послуг та відповідної моделі його реформування в роботі виконується за допомогою системного підходу, методів раціонального вирішення проблем та стратегічного планування за певним сценарієм, який виконується за такою послідовністю, рис. 3.

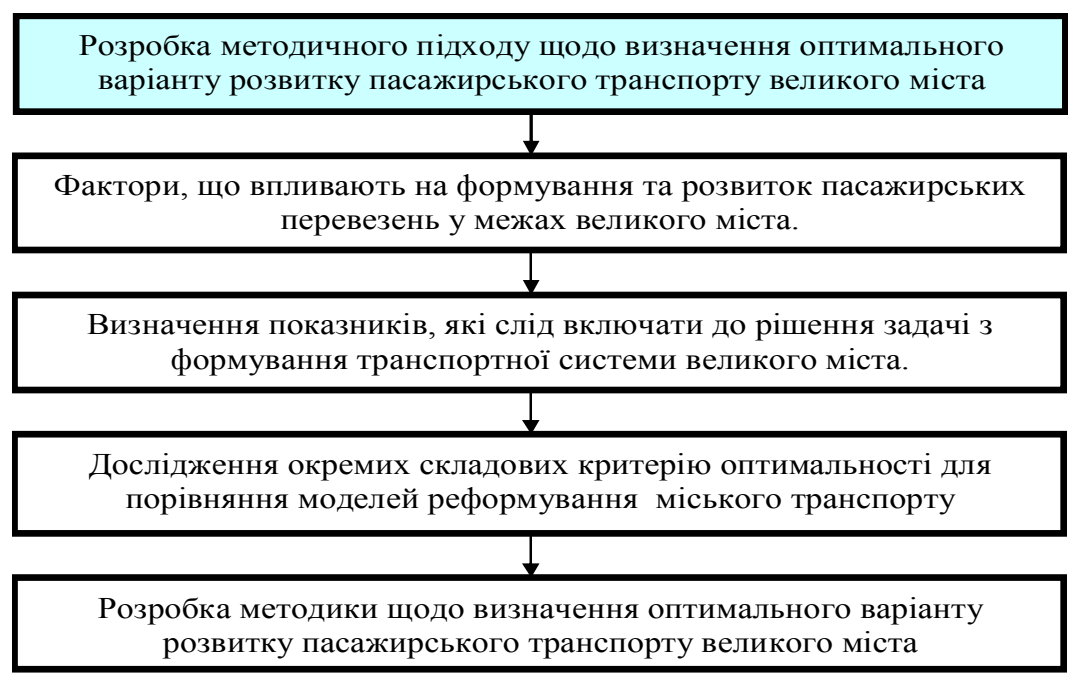

Рис. 3 - Послідовність проведення досліджень стосовно оптимізації міських пасажирських перевезень. Джерело: Розробка автора

Проблема рішення цієї задачі полягає в тому, що існує декілька комплексних підходів до їі рішення, але жоден 3 них не враховує усі технологічні, соціальні та екологічні фактори, що значно впливають на іï оптимальне рішення. Декларуючи рішення задачі оптимізації міських пасажирських перевезень 3 позиції сталого розвитку, науковці не вирішують такі задачі:

- ліквідацію технологічних заторів;

- заміну автомобільного міського транспорту на інші більш безпечні види транспорту; 
- зміну організації руху деяких видів транспорту;

- отримання позитивного ефекту від зменшення смертності та кількості захворювань населення;

- отримання соціального ефекту від скорочення терміну, підвищення якості та зручності поїздки пасажирів.

Запропонований методичний підхід пропонує розглядати проблему оптимізації міських пасажирських перевезень 3 урахуванням мінімізації витрат за трьома напрямками:

- оптимізації перевезень за рахунок раціональної експлуатації усіх видів міського транспорту, утримання транспортної інфраструктури та мінімізації інвестицій на їх розвиток;
- удосконалення міських транспортних перевезень 3 позиції мінімізації шкоди, яку вони завдають суспільству та навколишньому середовищу з урахуванням негативного впливу на здоров’я мешканців мегаполіса;

- оптимізації міських пасажирських перевезень з позиції соціального захисту населення великих міст за рахунок часткової ліквідації технологічних заторів та аварій, що призводять до загибелі людей, або інших негативних наслідків.

Для розробки науково-методичного підходу щодо ефективного впровадження різних видів транспорту в великих містах України спочатку слід їх класифікувати за видами сполучення та розробити основі принципи їх використання (рис. 4).

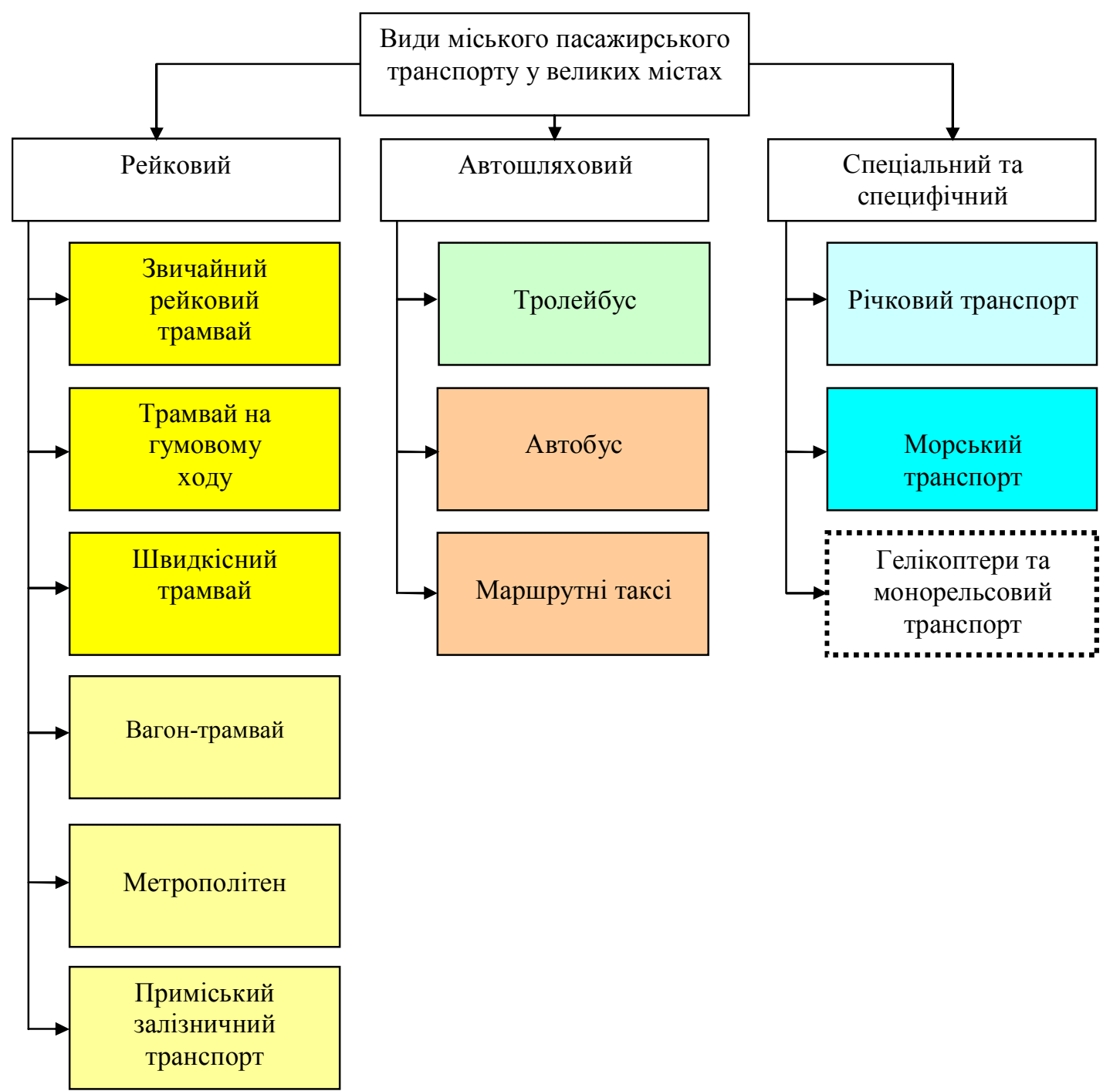

Рис. 4 - Класифікація міського транспорту для перевезення пасажирів у великих містах. Джерело: Розробка автора 
До рейкових видів транспорту, який $є$ найбільш надійним, екологічним та безпечним, слід віднести:

- Звичайний рейковий трамвай;

- Трамвай на гумовому ходу;

- Швидкісний трамвай, який прокладається на землі або під землею;

- Метрополітен;

- Приміський залізничний транспорт;

- Вагон-трамвай.

Ці види транспорту слід впроваджувати в великих містах у першу чергу для заміни автомобілів і автобусів на рідкому паливі або гасі, які завдають найбільшої шкоди населенню та навколишньому середовищу. віднести:

До автомобільних видів транспорту можна

- Автобуси на рідкому паливі та гасі;

- Автобуси на електричному живленні;

- Маршрутні таксі;

- Тролейбуси (але їх відносять до електротранспорту).

Окремо в класифікації займають місце водні види транспорту в містах, які розташовані на березі моря, або де протікають середні або великі річки:

- Річковий транспорт;

- Морський транспорт.

Крім того, в Україні можна використовувати спеціальний міський транспорт: гелікоптери та монорельсовий транспорт. Ці два останніх види транспорту в Україні майже не використовуються.

Для вирішення задачі щодо оптимального розвитку транспорту у великих містах слід застосувати такий економічний критерій, який би міг врахувати найбільшу кількість чинників, що адекватно описують поведінку моделі реформування. Але оцінити усі фактори, що впливають на вибір раціонального розвитку міського пасажирського транспорту не можливо, оскільки дуже складно розрахувати витрати на боротьбу 3 його негативним впливом на навколишне середовище та технологічними заторами.

Цю проблему можна вирішити також за допомогою методу експертних оцінок. Але цей підхід напряму залежить від кількості та компетенції експертів, що призводить до значної похибки.

Для більш точного вирішення цієї задачі можна поєднати одночасно вказані вищі підходи, що дозволить врахувати усі економічні показники та фактори сталого розвитку суспільства, а саме: аварії, шум, забруднення повітря, зміну клімату, вплив на природу, міські, індустріальні ефекти, витрати на боротьбу 3 хворобами та відшкодовування збитків мешканців та підприємств міста.

Оцінити усі вказані вище фактори в одній роботі дуже складно, тому автор зробила спробу розробити загальний науковий підхід до вирішення цієї проблеми й одночасно розробити методи оцінки витрат на боротьбу зі шкодою від навколишнього середовища на здоров'я мешканців міста та на компенсації шкоди від технологічних заторів.

3 урахуванням сказаного вище можна запропонувати критерій, за яким слід визначати ефективність $K_{e \phi}$ будь-якого виду міського пасажирського транспорту. Для цього пропонується узагальнюючий показник ефективності, (УПЕ), який математично можна записати за допомогою формули (1):

$$
\mathrm{У} П=\sqrt[12]{\left(\mathrm{K}_{\mathrm{eq}}\right) \times\left(\mathrm{K}_{\mathrm{aв}}\right) \times\left(\mathrm{K}_{\text {ш }} \times \mathrm{K}_{\text {зп }} \times \mathrm{K}_{\text {зк }} \times \mathrm{K}_{\text {вп }} \times \mathrm{K}_{\text {ме }}\right) \times\left(\mathrm{K}_{\text {цін }} \times \mathrm{K}_{\text {рп }} \times \mathrm{K}_{\text {яп }} \times \mathrm{K}_{\text {шв }} \times \mathrm{K}_{\text {оч }}\right)},
$$

де $\mathrm{K}_{\mathrm{e \phi}}$ - показник, що враховує економічну

ефективність даного виду міського пасажирського транспорту 3 урахуванням обсягів інвестицій на утримання та розвиток транспортної інфраструктури;

$\mathrm{K}_{\mathrm{aв}}$ - показник, що враховує техногенну обстановку, яку створює транспорт у місті;

$\mathrm{K}_{\text {ш }}$ - показник, що враховує рівень шуму, який створює транспорт у місті;
$\mathrm{K}_{\text {зп }}$ - показник, що враховує рівень забруднення повітря, який створює транспорт у місті;

$\mathrm{K}_{\text {зк }}$ - показник, що враховує рівень зміни клімату, який створює транспорт у місті;

$\mathrm{K}_{\text {вп }}$ - показник, що враховує рівень впливу на природу, який створює транспорт у місті;

$\mathrm{K}_{\text {ме }}$ - показник, що враховує рівень впливу місцевих ефектів, який створює транспорт у місті; 
$\mathrm{K}_{\text {цін }}$ - показник, що враховує ціну, за якою надається послуга даним видом транспорту;

$\mathrm{K}_{\text {рп }}$ - показник, що враховує ритмічність перевезення пасажирів даним видом транспорту;

$\mathrm{K}_{\text {яп }}$ - показник, що враховує якість перевезень, надану даним видом транспорту;

$\mathrm{K}_{\text {шв }}$ - показник, що враховує швидкість доставки пасажирів даним видом транспорту до пункту призначення;

$\mathrm{K}_{\text {оч }}$ - показник, що враховує термін та

зручність очікування поїздки даним видом транспорту;

Серед вказаних вище показників можна виділити чотири групи складових: показник економічної ефективності місцевих видів транспорту $\left(\mathrm{K}_{\mathrm{e \phi}}\right)$, показник, що враховує негативні наслідки від діяльності міського транспорту $\left(\mathrm{K}_{\mathrm{aв}}\right)$, показники, що враховують негативні наслідки від транспорту на суспільство та навколишнє
$\left(\mathrm{K}_{\text {ш }}, \mathrm{K}_{\text {зп }}, \mathrm{K}_{\text {зК }}, \mathrm{K}_{\text {вп }}, \mathrm{K}_{\text {ме }}\right)$ та показники, що характеризують якісні та кількісні фактори кожного 3 видів міського пасажирського транспорту $\left(\mathrm{K}_{\text {цін }}, \mathrm{K}_{\text {рп }}, \mathrm{K}_{\text {яп }}, \mathrm{K}_{\text {шв }}, \mathrm{K}_{\text {оч }}\right)$ i які найбільш турбують мешканців міста. Для більш наочного представлення кожна 3 чотирьох складових взята у дужки. Виникає важливе питання - чи всі перелічені показники однаково впливають на загальний показник УПЕ? Для цього слід виконати додаткові дослідження окремо за кожним 3 показників.

По-перше, слід сказати, що останні п'ять показників ефективності $є$ повним відображенням показника $\mathrm{K}_{\mathrm{e \phi}}$, оскільки останній враховує не тільки доходи від перевезень, а й експлуатаційні витрати і ефективність діяльності даного виду транспорту. Крім того, показник ефективності $\mathrm{K}_{\text {цін }}$ можна виключити, так як в останні часи в України пропонується порівняти ціни на усі види міського транспорту, як це роблять за кордоном. Зважаючи на сказане, показники $\left(\mathrm{K}_{\text {цін }}, \mathrm{K}_{\text {рп }}, \mathrm{K}_{\text {яп }}, \mathrm{K}_{\text {шв }}, \mathrm{K}_{\text {оч }}\right)$ слід виключити 3 узагальнюючого показника УПЕ. Після перетворень формула (1) набуде вигляду (2):

$$
\text { УПЕ }=\sqrt[7]{\left(\mathrm{K}_{\mathrm{eq}}\right) \times\left(\mathrm{K}_{\mathrm{aв}}\right) \times\left(\mathrm{K}_{\mathrm{ш}} \times \mathrm{K}_{3 \Pi} \times \mathrm{K}_{\text {зК }} \times \mathrm{K}_{\text {вп }} \times \mathrm{K}_{\mathrm{ме}}\right)},
$$

Але тепер стало зрозумілим те, що для суттєвого підвищення рентабельності пасажирських перевезень, яка визначається показниками економічної ефективності $\mathrm{K}_{\text {еф }}$, необхідно:

1. Визначати та встановити раціональні тарифи на перевезення пасажирів різними видами транспорту, які б дозволили позитивно впливати на рентабельність перевезень.

2. Підвищити ритмічність перевезень пасажирів за умови визначення оптимального співвідношення між кількістю рейсів транспорту та витрат на перевезення.

3. Суттєво підвищити якість послуг, що надаються перевізниками різних видів транспорту.

4. Підвищити швидкість руху міських видів транспорту 3 урахування зручності курсування протягом доби.

5. Оптимізувати час проїзду та зручність доставки мешканців міста до місця отримання послуги у прямому та зворотному напрямках.

6. Суттєво скоротити термін очікування послуги на зупинках.

7. Значно скоротити експлуатаційні витрати на перевезення пасажирів за рахунок новітніх технологій, науково обгрунтованої організації руху транспорту, впровадження нового рухомого складу та ін.

Запропонований узагальнюючий показник ефективності має багато спільного 3 показниками інтенсивності конкуренції, які представлені в методичній літературі [12, с. 40-41] та дисертації [11], але сутність його зовсім інша.

В даній статті розроблено узагальнюючий показник оцінки ефективності міських пасажирських перевезень, який грунтується на поєднанні коефіцієнтів, що характеризують: економічну ефективність міського пасажирського транспорту з урахуванням обсягів інвестицій на утримання та розвиток транспортної інфраструктури; техногенну обстановку, яку створює транспорт у місті; шкоду, яку кожний вид транспорту завдає довкіллю та суспільству. Запропонований показник дозволяє об'єктивно порівняти ефективність пасажирських перевезень за кожним видом транспорту окремо.

Висновки за даними дослідженнями та перспективи подальших досліджень у даному напрямку. Дослідження показали, що для вирішення задачі щодо оптимального розвитку транспорту у великих містах слід застосувати 
такий економічний критерій, який би міг врахувати найбільшу кількість чинників, що адекватно описують поведінку моделі реформування.

Оцінити усі вказані вище фактори в одній роботі дуже складно, тому автор зробила спробу розробити загальний науковий підхід до вирішення цієї проблеми й одночасно розробити методи оцінки витрат на боротьбу зі шкодою від навколишнього середовища на здоров'я мешканців міста та на компенсації шкоди від технологічних заторів.

В наступних роботах будуть проведені дослідження стосовно: визначення факторів, що впливають на формування та розвиток пасажирських перевезень у межах великого міста; виявлення сутності показників, які слід включати до рішення задачі 3 формування транспортної системи великого міста; дослідження окремих складових критерію оптимальності для порівняння моделей реформування міського транспорту, розробки методики щодо вибору оптимального варіанту розвитку пасажирського транспорту великого міста.

\section{СПИСОК ЛІТЕРАТУРИ}

1. Гаевская Л. Н. Экономические аспекты развития железнодорожного транспорта Украины [Электронный ресурс] / Л. Н. Гаевская. - Ирпень, 2001. Режим доступу: http://in1.com.ua/book/12197/9891/

2. Зеркалов Д. В. Транспортна система України. - К.: Основа, 2006. - 704 с.

3. Качан Є. П. Розміщення продуктивних сил України: (розміщення галузей транспортного комплексу) [Електронний ресурс] / Є. П. Качан, М. О. Ковтонюк, М. О. Петрига та ін.; За ред. Є. П. Качана. - К.: Вищ. шк., 1997. - 365 с. Режим доступу: http://www.library.if.ua/book/69/5089/html

4. Кудрицька Н. В. Соціально-економічні аспекти розвитку транспортно-дорожного комплексу України // Залізничний транспорт України, № 5, 2009. - с. 32-34.

5. Сидоренко I. В. Транспортно-дорожній комплекс регіону: стан та проблеми [Електронний ресурс] / І. В. Сидоренко // Вісник ЧДТУ: Зб. Наук. праць. - Чернігів: ЧДТУ, 2007. - № 29. Режим доступу: $\quad$ http//www.nbuv.gov.ua/portal/SocGum/Vcndtu/2009_39/32 htm

6. Корженевич I. П., Бараш Ю. С., Мельянцова Ю. П. Сучасний підхід до вибору транспортної системи великого міста // Вісн.
Дніпропетр. нац. ун-ту залізн. трансп. ім. акад. В. Лазаряна. - Д.: Вид-во Дніпропетр. нац. ун-ту залізн. трансп. ім. акад. В. Лазаряна, 2009. - Вип. 15. - C. 225-232.

7. Мельянцова Ю. П. Вплив міського транспорту на сталий розвиток великих міст // Тези доповідей на VIII Міжнародну конференцію «Проблеми економіки транспорту» / Дніпропетр. нац. ун-т залізн. трансп. ім. акад. В. Лазаряна. - Д., 2009. - C. 54.

8. Мельянцова Ю. П. Розвиток пасажирського транспорту великих міст 3 позиції сталого розвитку суспільства // Збірник наукових праць Дніпропетровського національного університету залізничного транспорту імені академіка В. Лазаряна «Проблеми економіки транспорту» - Вип. 1. - Д.: Вид-во Дніпропетр. нац. ун-ту залізн. трансп. ім. акад. В. Лазаряна, 2011. - С. 96-101.

9. Мельянцова Ю. П. Сучасний стан міського транспорту великих міст // Материалы V Международной научно-практической конференции «Проблемы экономики и управления на железнодорожном транспорте» - ЭКУЖТ 2010 24-26 ноября 2010 года, г. Яремча. - с. 72.

10. Мельянцова Ю. П. Теоретикометодический подход к оценке различных видов городского транспорта // Научно-теоретический и практический журнал «Современный научный вестник», 2012. - Вып. 18 (130). - С. 43-47.

11. Чаркіна Т. Ю. Управління конкурентоспроможністю залізничних пасажирських перевезень на ринку транспортних послуг : дис. ... канд. екон. наук / Т. Ю. Чаркіна. Х. : УкрДАЗТ, 2013. - 256 с.

12. Юданов А. Ю. Конкуренция: Теория и практика : учебное пособие

А. Ю. Юданов. -3 изд. - М. : Гром-Пресс, 2002. $381 \mathrm{c}$.

13. Гусев С. А., Маросин В. С. Правовое поле организации работы городского пассажирского транспорта: анализ состояния // Вестник развития науки и образования. - 2014. № 2. - С. 172-177.

14. Славина Ю. А. Методические положения по расчету показателей развития системы городского пассажирского транспорта // Вестник развития науки и образования. - 2014. № 2. - C. 178-182.

15. Семчугова Е. Ю., Негров Н. С. Обеспечение мобильности населения в системе городского пассажирского транспорта // Научное обозрение. - 2014. - № 9-3. - С. 1022-1026.

Експерт редакційної колегії к.е.н., доцент УкрДАЗТ Слагін Ю.В. 